\title{
Searching for coherence in language teaching: the issue of teaching competencies
}

Carlos Rico Troncoso

\begin{abstract}
This document is an attempt to show some theoretical issues teachers should take into account when adopting the commitment of teaching languages. Many things haven been said about teaching languages, but there has not been any systematic reflection about teaching a foreign language in our context. Our foreign language history has shown that Colombian teachers implement many things in their classrooms without realizing the impact of those implementations in the theoretical and practical field. Nowadays, some changes have been given to the New ICFES State Examination, and The Ministry of Education (MEN) has proposed in the curricula orientations the language competence education. Due to these new demands, it is necessary to revise the way how a foreign language is taught in our educational context. To this respect, the present paper will mention some of the most important aspects teachers should reflect upon when dealing with language teaching. The first thing to do is to define the approach or the method to be used (the nature of language and of language learning) second, it is necessary to define the design to be implemented according to the theory proposed. The design will deal with the teaching objectives, the type of syllabus adopted (content choice and organization), the types of learning and teaching activities, the learner and teachers roles, and the role of instructional materials.
\end{abstract}

Key words: Second Language Acquisition, Teaching Languages by competencies, approach and design.

\section{Resumen}

Este artículo busca mostrar algunos aspectos teóricos que deberían ser tenidos en cuenta cuando se opta por una enseñanza de lenguas. Mucho se ha dicho acerca de la enseñanza de lenguas, pero no ha habido una reflexión sistemática acerca de lo que es enseñar lenguas extranjeras en nuestro contexto. Muchos maestros implementan metodologías sin prever el impacto que éstas puedan tener en el aula. Hoy en día tanto el ICFES (Examen de Estado) como el MEN proponen unas orientaciones curriculares en torno a una educación por competencias. Este artículo presenta algunos elementos teóricos claves a considerar en la enseñanza de una lengua. En este sentido, se menciona la importancia en definir el enfoque y el método a trabajar (Aquí se precisa sobre la naturaleza de la lengua y del aprendizaje) seguidamente, se define el diseño a ser implementado de acuerdo con el enfoque adoptado. En el diseño se definen los objetivos de enseñanza, el tipo de sílabo, las diferentes actividades de enseñanza y aprendizaje, los roles del maestro y del aprendiz y el rol de los materiales de instrucción.

Palabras claves: Adquisición de una segunda lengua, Enseñanza de lenguas por competencias, enfoque, método.

\footnotetext{
* Received: 18-02-05 / Accepted: 25-06-05
} 
This document is an attempt to show some theoretical issues teachers should take into account when adopting the commitment of teaching languages. Many things haven been said about teaching languages, but there has not been any systematic reflection about teaching a foreign language in our context. Our foreign language history has shown that Colombian teachers implement many things in their classrooms without realizing the impact of those implementations in the theoretical and practical field. Nowadays, some changes have been given to the New ICFES State Examination, and The Ministry of Education (MEN) has proposed in the curricula orientations for developing language competence. To this respect, the present paper will mention some of the most important aspects teachers should reflect upon when dealing with a language teaching. The first thing to do is to define the approach or the method to be used (the nature of language and of language learning) second, it is necessary to define the design to be implemented according to the theory proposed. The design will deal with the teaching objectives, the type of syllabus adopted (content choice and organization), the types of learning and teaching activities, the learner and teachers roles, and the role of instructional materials.

The reflection on all the former aspects should be the point of departure in the improvement of the quality of language teaching nowadays. In this sense, language teachers should start re-thinking about what they do and how they do it in their classrooms. In relation to this point, Corder (1973:139) suggests two questions which the language teacher can ask and which are of interest to the applied linguist or, said differently, applied linguistics can help answer two questions concerning language teaching: what to teach and how to teach it. We need to know precisely what it is about the language we are teaching and to do this, we need to know something about language, or Lingusitics, and be able to apply this to our teaching situation.

Regarding the second question how to teach it, Corder suggests that the contents of the syllabus will directly influence the type of methodology that is employed in the classroom and vice versa. In other words, if a teacher is following a structural syllabus, s/he will probably use a behaviourist methodology, whereas if $\mathrm{h} /$ she is following a notional-functional syllabus, $\mathrm{h} / \mathrm{she}$ will most likely use communicative methodology.

When considering the first question, it was hinted that students learn items of language that are not included in the syllabus that is being followed. This is 
an important point, and should not be overlooked. In fact, Ellis has suggested that there is a hidden syllabus which the learner follows. This observation is made clearer when we consider not only that learners seem to learn aspects of language that we have not set out to teach, but also, that we are not in the position yet to give a completely comprehensive description of any language, let alone English. As such it has been claimed that learners learn some items of language without the benefit of systematic and deliberate teaching (Corder, 1973:142) and even that they learn language in spite of what teachers do, and not because of it.

We have now considered approaches to the questions of what to teach and how to teach it, but we must turn our attention to the issue of whether or not what we teach actually influences what is learnt by the student. In other words, we need to change our focus of attention from that of language learning or, see what happens in the classroom from the learner's perspective rather than that of the teacher. Obviously, the relation between what is taught and what is learnt is a complex one and is influenced by many factors which are both linguistic and non-linguistic.

Regarding the linguistic factors, Ellis (1985), devotes a chapter to the question: Does formal instruction aid SLA? In which he assesses the research evidence which compares both, the order in which learners learn structures and the rate of success they have in doing so in the classroom (when they are studying a foreign language) when compared with learners who have the opportunity to acquire the second language in a natural environment. The conclusions he makes are not definitive, he does suggest that research evidence seems to show that formal classroom instruction can help learners to learn structures faster than those who are exposed to them in a natural environment.

When talking about acquiring and learning any language it is necessary to consider many factors that are interrelated, those which are related to the student (individual learner differences) and those which are related to the settings where the language learning takes place (social factors). Stern, H.H (1987:274) shows how the social factors are connected with the language teaching. Here there are the elements we might consider as the social factors which intervene in the language teaching and learning. 


\section{EDUCATIONAL}

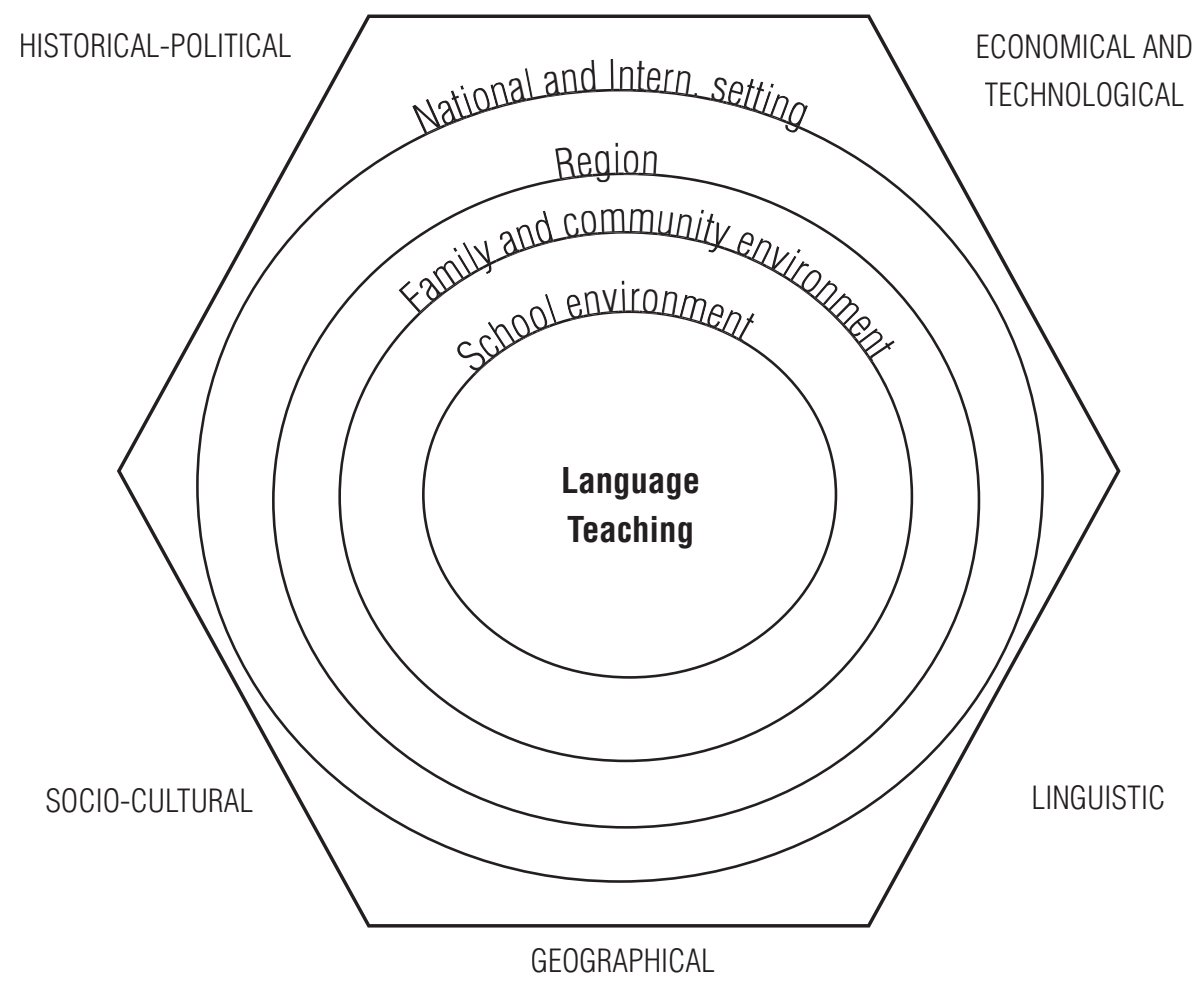

(Taken from: Stern, H.H. (1987) An adaptation of Mackey's and Spolsky's diagrams combined as an inventory of contextual factors in Language teaching)

Undoubtely, all decisions one makes in terms of teaching and learning languages might take as reference the social conditions of the learner is, for example the educational setting (teaching proficiency, skills or competencies), the historical and political conditions (EFL or ESL settings) the economical and technological resources (aids for mediating the process), the linguistic features (Monolingual or bilingual environment) and the geographical location (international or intranational language).

Definitely, it is not enough to consider the social factors which influence the learning or the acquisition of any language. It is also important to analyze the personal characteristics of the individual (beliefs, affective states, learner's experience), in certain degree, they affect the learning/acquisition process. 
To this respect, Ellis, Rod (1994:530) points out how the individual learner differences and the situational and social factors should be considered when teaching and learning any second language. He says the learning outcomes are the product of the integration of the individual learner differences and the social factors. This integration is represented as follows:

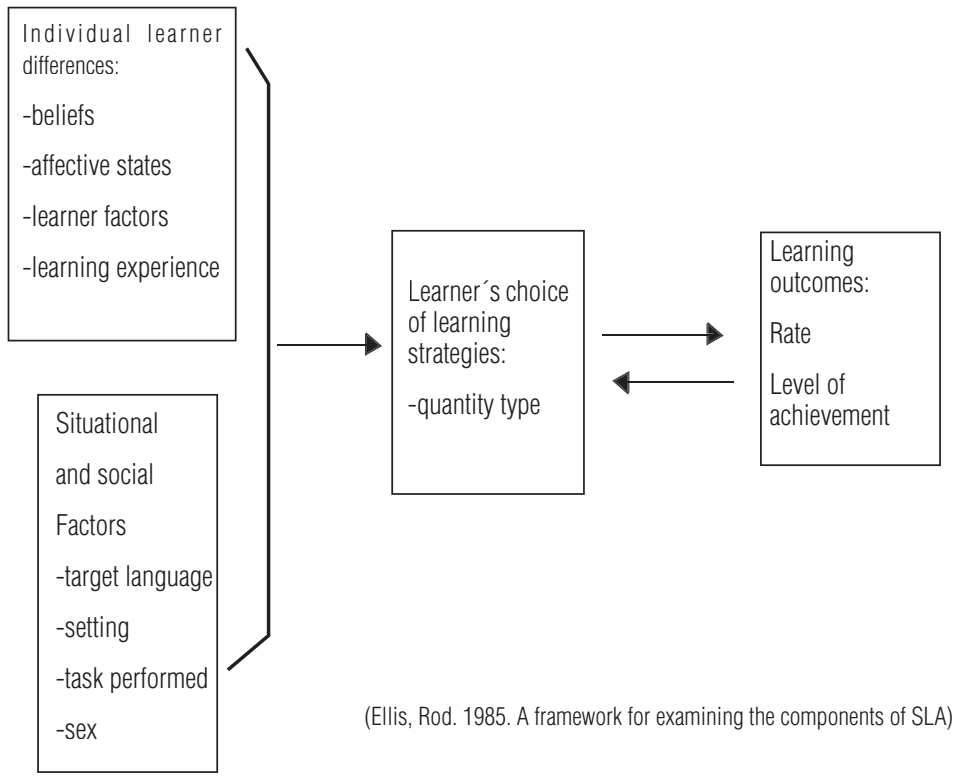

Up to this point the question is how to integrate all these factors to get the expected students' outcome that is to develop real language learning. The answer should be to bridge the gap between the what and the how of language teaching, in other words, to make possible the coherence between theory and the practice. First of all, it is necessary to know the theory about the nature of language and language learning that serve as the source of practices and principles in language teaching.

In the theory of language teachers have to consider at least three theoretical views. The first and the most traditional one is the structural view, which consists of the language as a sytem of structurally related elements for the coding of meaning. The level of proficiency is seen according to the student's capacity to recognize and master the elements of the system, which is generally defined in terms of phonological units (phonemes), grammatical units (clauses, phrases, sentences), grammatical operations (adding, shifting, 
joining, or transforming elements) and lexical items (function words, and structure words)

The second view of language is the functional view. Here language is viewed as a vehicle for the expression of functional meaning. This theory, according to Richards and Rodgers (1986), emphasizes the semantic and communicative dimension rather than the grammatical characteristics of language, and leads to a specification and organization of language teaching content by categories of meaning and function rather than by elements of structure and grammar. Students learn notions, topics and concepts they will need to communicate with.

The last view of language can be called the interactional view. It sees language as a vehicle for the realization of interpersonal relations and for the performance of social transactions between individuals. Here language is viewed as a tool of creation and maintenance of social relations. Interactional theories focus on the patterns of moves, acts, negotiation, and interaction found in conversational exchanges.

These three views of language provide teachers with the theory that they will need at the moment of teaching any language. Teachers must be sure about the most suitable methodology to be implemented in the classroom to achieve the expected learning objectives. Moreover, these three models of language (or variation on them) provide the axioms and theoretical framework that may motivate a particular teaching method. Obviously, they may be completed with a theory of language learning. This is the dimension that will be explained now.

A learning theory should answer two questions: a) What are the psycholinguistic and cognitive processes involved in language learning? and b)What are the conditions that need to be met in order for this learning processes to be activated?. There are theories based on process, such as habit formation, induction, inference, hypothesis testing, and generalization, and there are theories based on conditions which emphasize the nature of the human and physical context in which language learning takes place.

When teaching a language it is important to consider what is the theory of language learning to be followed. To this point it is necessary to make a distinction between acquisition and learning. The former refers to the natural 
assimilation of language rules through using language for communication. The latter refers to the formal study of language rules through a conscious process. Krashen, in Ellis (1985) addresses the conditions necessary for the process of acquisition to take place. He describes these in terms of the type of input the learner receives. Krashen claims that when students develop competences, they are making links between the acquired competence and the learnt competence, and that is what students produced. See the following diagram.

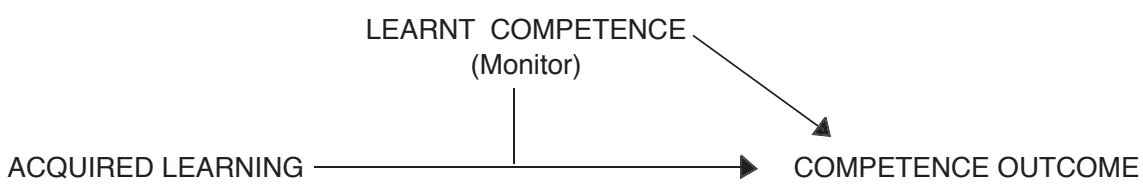

(Monitor Model, Krashen, 1981)

Charles A. Curran (in Richards and Rodgers, 1986) in his writings on counseling-learning, focuses primarily on the conditions necessary for successful learning. He believes that the atmosphere of the classsroom is a crucial factor, and that is why his method seeks to ameliorate the feelings of intimidation and insecurity that many learners experience. One of the examples in which it is possible to see the importance of a learning theory is in Asher's method (Total Physical Response TPR). His theory addresses both the process and condition aspects of learning. It is based on the belief that child language learning is based on motor activity, on coordinating language with action, and that this should form the basis of adult foreign language teaching. Orchestrating language production and comprehension with body movement and physical actions is thought to provide the conditions for success in language learning.

Maybe, one of the examples in which we can see the coherence between the theory of language and the theory of learning is the method called Audiolingualism. The linking of structuralism (a linguistic theory) to behaviorism (a learning theory). With respect to language theory researchers are concerned with a model of language competence and account of the basic features of linguistic organization and language use. And with respect to learning theory, researchers are concerned with an account of the central processes of learning and an account of the conditions believed to promote successful 
language learning. Teachers may, for example, develop their own teaching procedures, informed by a particular view of language and a particular theory of learning. They may constantly revise, vary, and modify teaching/learning procedures on the basis of the performance of the learners and their reactions to instructional practice.

Based on the above it is important that teachers adopt a theory of language and a theory of learning, from which they can design their language courses, and they can mention the scope of their language classes. A group of teachers holding similar beliefs about language and language learning may each implement these principles in different ways. Approach does not specify procedure. Theory does not dictate a particular set of teaching techniques and activities. What links theory with practice is what it is called design.

Up to this part we have seen the importance of considering a theory of language and a theory of learning, but how can we see the integration of these aspects in the classroom? The answer is easy, only through the DESIGN because it is the level in which things are put into action. Rodgers (1986) claims that the design specifies the objectives of the method, how language content is selected and organized within the method, that is, the syllabus model, the types of learning tasks and teaching activities the method advocates, the role of the learners, the roles of teachers, and the role of instrucctional materials.

In regards to the first one, the objectives, different theories of language and language learning influence the focus of the objectives. Some methods focus primarily on oral skills and say that reading and writing skills are secondary and derive for transfer of oral skills. Some methods set out to teach general commmunication skills and give greater priority to the ability to express oneself meaningfully and to make oneself understood than to grammatical accuracy or perfect pronunciation. Others place a greater emphasis on accurate grammar and pronunciation from the very beginning. There some others who may define their objectives less in linguistic terms that in terms of learning behaviors, that is, in terms of the process or abilities the learner is expected to acquire as a result of instruction.

In relation to the way contents are organized, all methods involve decisions concerning the selection of language items (words, sentence patterns, tenses, constructions, functions, topics, etc). Decisions about the choice of language content relate both to subject matter and linguistic matter. The first one has to 
do with decisions about what to talk about (subject matter), and the second how to talk about it (linguistic matter).

In grammar-based courses matters of sequencing and gradation are generally determined according to the difficulty of items or their frequency. In communicative or functionally oriented courses (for instance in ESP programs) sequencing may be according to the learners'communicative needs. Traditionally the action of selecting and grading contents is referred to as syllabus. For example, notional-functional syllabuses specify the communicative content of a course in terms of functions, notions, topics, grammar and vocabulary. Such syllabuses are determined in advanced, for that reason it has been referred to as "a priori action".

In terms of the types of learning and teaching activities, teachers should consider first the objectives proposed, and then the materials they have to work with. Teaching activities that focus on grammatical accuracy may be quite different from those that focus on communicative skills. Activities designed to focus on the development of specific psycholinguistic processes in language acquisition will differ from those directed toward mastery of particualr features of grammar. For example, the communicative, approach advocates the use of tasks that involve an "information gap" and "information transfer"; that is, learners work on the same task, but each learner has different information needed to complete the task. Differences in activity types in methods may also involve different arrengements and groupings of learners. A methodology which will consist of oral chorus drilling, will require different groupings of learners in the classroom from a methodology which uses problem-solving/informationexchange activities involving pair work.

For the design stage it is also important to consider the learner roles, "the design of an instructional system will be considerably influenced by how learners are regarded". The methods reflect explicity or implicity the way students contribute to the leaning process. We can see this through the types of activities students carry out, the degree of control learners have over the contents, the patterns of learner groupings adopted, the degree to which learners influence the learning of others, and the view of the learner as processor, performer, initiator, problem solver.

Actually, the learners' role is adopted depending on the type of activity $\mathrm{s} /$ he is involved in, and the method the teacher follows. For instance, it is 
not possible to ask student to solve problems or exchange information with another student if $\mathrm{s} / \mathrm{he}$ is working on a mechanical drilling exercise, because the learner is seen as stimulus-response mechanism whose learning is a direct result of repetitive practice. As it was mentioned by Richards and Rodgers (1986) there are some of the expected roles, from learners if an individualized approach were adopted:

- Learners plan their own learning program. They assume responsibility for what they do in the classroom

- Learners monitor and evaluate their own progress

- Learners are members of the group and learn by interacting with others

- Learners tutor other learners

- Learners learn from the teacher, from other students, and from other teaching sources

We were saying that the learner roles are related to the types of activities and material they have to deal with, and those roles are closely linked to the teacher's status and function. In case of the teacher roles, they are related ultimately both to assumptions about language and language learning at the level of approach. There are some methods and methodologies that are dependent on the teacher as a main source of knowledge and direction, others see the teacher's role as catalyst, consultant, guide, and model for learning.

Both, teacher and learner roles define the type of interaction characteristic of classrooms in which a particular methodology is being used. According to Richards and Rodgers (1986), teacher roles are related to the following issues:

- The types of functions teachers are expected to fulfill, whether that of practice director, counselor, or model, for example.

- The degree of control the teacher has over how learning takes place

- The degree to which the teacher is responsible for determining the content of what is taught

- The interactional patterns that develop between teachers and learners 
Generally speaking, our methodologies depend on the teacher roles, the teacher is regarded as the primary source of language and of language learning. For individualized approaches to learning it is necessary to define roles for the teacher that creates specific interaction patterns on between teachers and learners in the classroom. These are designed to shift the reponsibility for learning gradually from the teacher to the learner. "The role of the teacher will ultimately reflect both the objectives of the method and the learning theory on which the method is predicated, since the success of a method may depend on the degree to which the teacher can provide the content or create the conditions for successful language learning".

The last component in the level of design has to do with the role of the instructional materials within the instructional system. The materials specify the subject matter content and define or suggest the intensity of coverage for syllabus items allocating the amount of time, attention, and detail particular syllabus items or tasks require. Materials also define the day-to-day objectives that constitute the syllabus. The material can be done by the teacher or by the student or simply it can be taken from a series. There are some materials that require specially trained teachers with near native competence in the target language. Some are designed to replace the teacher, so that learning can take place independently. Some materials dictate various interactional patterns in the classroom, others inhibit classroom interaction.

The role of instructional materials reflect decisions concerning the primary goal of materials (to present content, to practice content, to facilitate communication between learners, or to enable learners to practice content without the teacher's help), the form of the materials (textbooks, audiovisuals, computer software), the relation of material to other sources of input (whether they serve as the major source of input or only as a minor component of it), and the abilities of teachers (their competence in the language or degree of training and experience).

The roles of the instructional material for a communicative and interactional methodology would be specified as follows:

- Materials will focus on the communicative abilities of interpretation, expression and negotiation

- Materials will focus on understandable, relevant, and interesting exchanges of information, rather than on the presentation of grammatical form 
- Materials will involve different kinds of texts an different media, which the learners can use to develop their competence through a variety of different activities and tasks.

Up to this point, we have seen that when adopting new changes we have to reflect on many things at the same time, but more than the reflection itself, we are demanded on finding the coherence among all aspects related to the teaching process. We are professionals and as such we have to teach. Ask yourself how coherent you are with the theory of language, the theory of learning, and the design adopted. The idea is not to accept all the changes without questioning. You might see whether those changes are possible to hold in your own circumstances. Remember: Changes are not easy to adopt and they consume much time and effort, but they give us the opportunity to re-evaluate what we are doing.

\section{Bibliography}

Brown, Douglas. (1994) Principles of Language Learning and Teaching. Third edition. Prentice Hall Regents

Brown, Douglas. (1991) Teaching by Principles. Prentice Hall Regents

Brumfit, Christopher. (1984) Communicative Methodology in Language Teaching. The roles of fluency and accuracy. Cambridge University Press.

Corder, S.P. (1973) Introducing Applied Linguistics. Harmondsworth, Middlesex: Penguin Books.

Ellis, R. (1985). The study of second Language Acquisition. Oxford: Osford University Press.

Littlewood, William. (1981) Communicative Language Teaching. An Introduction. Cambridge University Press.

Nunan, David. (1988) Syllabus Design. Cambridge: Cambridge University Press.

Revell; Jane. (1979) Teaching Techniques for Communicative English. ELTS (Essensial Language Teaching Series). Macmillan.

Richards Jack C and Rodgers, Theodore. (1986) Approaches and Methods in Language Teaching: A description and analysis. Cambridge University Press.

Richards Jack C. The Context of Language Teaching 
Savignon J. Sandra. (1983) Communicative Competence: Theory and Classroom Practice. Texts and contexts in second language learning. Addison-Wesley Publishing Company.

Stern, H.H (1987) Fundamental Concepts of Language Teaching. Oxford University Press.

THE AUTHOR

Carlos Rico Troncoso Holds a M.A in Education from Universidad Pedagogica Nacional and CINDE (Centro Internacional de Desarrollo Humano)- He studied also a M.A in Spanish Linguistics at Instituto Caro y Cuervo. He holds a B.A. in Modern Languages from Universidad del Tolima. He currently works as Research Coordinator at the Language Department in Pontificia Universidad Javeriana and in the Master Program of Applied Linguistics at Universidad Distrital Francisco José de Caldas. crico@javeriana. edu.co 